\title{
Effect of Integrated Nutrient Management on Okra Production in Acid Soil
}

\author{
Bushra Islam Binte, Mahmuda Akter, Mariam Khanam, Md. Ashraful Alam, Md. Parvez Kabir, \\ Mohammed Zia Uddin Kamal
}

\section{ABSTRACT}

Integrated Nutrient Management (INM) is a novel strategy to achieve sustainable crop production in degraded soils through judicious and balanced plant nutrients utilization. Sole application of chemical fertilizers in crop production causes soil and environmental pollution. The present study was designed to assess the effects of application of organic manures conjointly with chemical fertilizers on growth and yield of okra in acid soil. The experiment was consisted of four treatments viz. $T_{0}$ [Control], $T_{1}$ [Recommended dose of chemical fertilizers (RDF)], $\mathbf{T}_{2}$ [Dolomite (D) @ 1t $\mathrm{ha}^{-1}+\mathrm{RDF}$ ], T3 [Poultry manure (PM) @ 3t ha $\left.\mathrm{h}^{-1}+\mathrm{RDF}\right], \mathrm{T}_{3}$ [Cow dung (CD) @ 5t ha $\left.\mathrm{ha}^{-1}+\mathrm{RDF}\right]$ with six replications in a randomized complete block design. The results indicated that the use of PM with RDF showed better performance in the growth and yield attributes of okra. Compared with others plots, the highest plant height $(114.10 \mathrm{~cm})$, fresh weight plant $^{-1}(591.58$ g) and dry weight plant $^{-1}(86.73 \mathrm{~g})$ were observed in the PM-treated plot. Similarly, the highest number of fruits plant ${ }^{-1}(20.33)$ and fruit yield $(13.58 \mathrm{t}$ $\mathrm{ha}^{-1}$ ) were also found in PM-treated plants. Therefore, under acidic soil conditions, organic and inorganic fertilization may have a significant positive impact on the growth and yield of Okra.

Keywords: Chemical fertilizers, lime, organic manures, Okra.
Submitted : November 02, 2021

Published : December 13, 2021

ISSN: $2684-1827$

DOI: 10.24018 /ejfood.2021.3.6.406

Bushra Islam Binte

Department of Soil Science, Bangabandhu Sheikh Mujibur Rahman Agricultural University, Gazipur 1706, Bangladesh. (e-mail: bushra@bsmrau.edu.bd) Mahmuda Akter

Department of Soil Science, Bangabandhu Sheikh Mujibur Rahman Agricultural University, Gazipur 1706, Bangladesh.

(e-mail: mahmuda@bsmrau.edu.bd)

Mariam Khanam

Department of Soil Science, Bangabandhu Sheikh Mujibur Rahman Agricultural University, Gazipur 1706, Bangladesh. (e-mail: mariam@bsmrau.edu.bd) Md. Ashraful Alam

Department of Soil Science, Bangabandhu Sheikh Mujibur Rahman Agricultural University, Gazipur 1706, Bangladesh. (e-mail: ashraful@bsmrau.edu.bd) Md. Parvez Kabir

Department of Soil Science, Bangabandhu Sheikh Mujibur Rahman Agricultural University, Gazipur 1706, Bangladesh.

(e-mail: parvezbsmrau@ gmail.com)

Mohammed Zia Uddin Kamal*

Department of Soil Science, Bangabandhu Sheikh Mujibur Rahman Agricultural University, Gazipur 1706, Bangladesh. (e-mail: zia@bsmrau.edu.bd)

*Corresponding Author

\section{INTRODUCTION}

Soil acidity is one of the major agricultural production constraints in certain parts of the world. Acidic of the soil $(\mathrm{pH}<5.5)$ curtails crop growth and yield by restricting the availability of essential primary nutrient largely phosphorus and secondary nutrients ( $\mathrm{Ca}, \mathrm{Mg}$ ), and micronutrients (Mo, B and $\mathrm{Zn}$ ) and toxic accumulation of iron, aluminum, and manganese [4], [11]. In addition, it impedes the activity of soil microorganisms because the $\mathrm{pH}$ range of 6.5-7.5 is the best condition for maximum existence of all microorganisms. Therefore, soil acidification may affect a variety of microbial mechanisms such as organic materials mineralization, recycling of nutrients, nitrification and nitrogen fixation are inhibited or slowed down, and ultimately promote soil health degradation [7]. Thus, in order to ensure food security, effective management strategies are needed to reduce and ameliorate soil acidification.

Sustainable management approach is a vibrant tactic to alleviate the adverse impacts soil acidity on crop production. Soil acidity can be ameliorated by applying different liming materials and other acid neutralizing sources such as organic manures [22]. Limes are $\mathrm{Ca}$ or $\mathrm{Mg}$ containing substances which are added to acid soils to adjust $\mathrm{pH}$ to the levels needed by the crop to be grown [27]. Liming is considered as efficient rectifying method in acidity degraded soil [11]. But due to high price, difficulty in application techniques and soil specific-rates, farmers are not willing to apply lime [16].

Organic manures are locally available materials may contribute to restore soil fertility. Therefore, organic 
amendments become a potential option for reclamation of acidity. Extensive usage of well-decomposed organic matter in acid soils improves the buffering capacity of the soil, reducing soil acidity by adsorbing organic anions with releasing hydroxyl ions in the process and enhancing supply of nutrients [15]. Organic manure improves the physical, chemical, and biological properties of soil, which improves crop productivity and maintains crop quality [24]. Organic matter incorporation has also been shown to have a substantial impact on carbon sequestration and retain mineral nutrients in soil [9]. Thus, in the tropics organic amendment plays a vital role on restoration degraded soil by enhancing sustainable soil health and forming complex with toxic substances [18].

However, for ensuring better profitability and higher crop production farmers are largely depends upon the chemical fertilizers. In most cases, chemical fertilizers are used to meet the quick nutritional demands of plants. Only reliance on chemical fertilizers is detrimental for soil health as it depletes soil fertility, diminishes soil productivity, and lowers agricultural output [8]. Moreover, the over-use of chemical fertilizers is a source of acidification [20], [6]. Organic manures from variety of sources might be an excellent alternative to chemical fertilizers in terms of crop productivity and soil qualities [12]. Hence, combined application of organic and inorganic fertilizer considering integrated nutrient management (INM) practice might be a noble approach for sustainable crop production in acidic soil. However, it is crucial to identify the low-cost inputs i.e rate and type of organic and inorganic fertilizers aimed at farmer's friendly INM combination for ensuring better productivity in acidic soil. Vegetable crops are feasible sources of vitamins and minerals which can play a significant. role in human nutrition and health regulation. Okra (Abelmoschus esculentus L.) is one of the most popular vegetables, grown mostly in rainy and summer seasons in Bangladesh. It belongs to the family Malvaceae and popularly known as bhendi, ladies's fingers etc. This vegetable is generally utilized for its delicate pods [17]. The performance of okra as a short duration crop is greatly influenced by proper nutrient management practices [10]. There is big knowledge gap in sustainable soil management of soil acidity in terrace soil. Thus, to enhance the cropping intensification in degraded soil, the present study was intended to explore the ameliorating effects of INM on growth and yield of okra under acidic soil condition.

\section{MATERIALS AND METHODS}

\section{A. Experimental Site and Soil Properties}

The field experiment was carried out at research farm of Department of Soil Science, Bangabandhu Sheikh Mujibur Rahman Agricultural University (BSMRAU), Gazipur, during February to June 2021. The experimental site was located at $24.09^{\circ} \mathrm{N}$ latitude and $90.26^{\circ} \mathrm{E}$ longitudes with an altitude of 8.2 meter from sea level and pertains to AEZ 28 (Madhupur tract) (Anonymous, 1989). The soil studied area fall in Inceptisols taxonomic order under Salna series the soil of the research area was characterized as Shallow Red Brown Terrace acidic soil having the $\mathrm{pH}$ value about 5.3, organic carbon $(0.75 \%)$, total nitrogen $(0.1 \%)$, available phosphorus (7.5 mg kg-1), available sulphur (20.75 mg kg-1) and exchangeable potassium $\left(0.15 \mathrm{cmol}(+) \mathrm{kg}^{-1}\right)$.

\section{B. Experimentation}

Five different nutrient management approaches viz. $\mathrm{T}_{0}$ [Control], $\mathrm{T}_{1}$ [Recommended dose of chemical fertilizers (RDF)], $\mathrm{T}_{2}$ [Dolomite (D) @ 1t ha ${ }^{-1}+\mathrm{RDF}$ ], T3 [Poultry manure (PM) @ $\left.3 \mathrm{tha}^{-1}+\mathrm{RDF}\right]$ and $\mathrm{T}_{4}[\mathrm{Cow}$ dung $(\mathrm{CD}) @ 5 \mathrm{t}$ $\left.\mathrm{ha}^{-1}+\mathrm{RDF}\right]$ were used as treatments in the study. The treatments were arranged in a randomized complete block design (RCBD) with six replications. One month old, decomposed poultry manure and cowdung and sundried for reduced the moisture. For liming dolomite was collected from local market. The nutritional contents of incorporated organic materials (poultry manure and cowdung) and dolomite are shown in Table I.

TABLE I: NUTRIENT CONTENT OF ORGANIC MANURES AND LIMING

\begin{tabular}{|c|c|c|c|c|c|c|c|c|}
\hline $\begin{array}{l}\text { Amending } \\
\text { substances }\end{array}$ & $\begin{array}{c}\mathrm{C} \\
(\%) \\
\end{array}$ & $\begin{array}{c}\mathrm{N} \\
(\%) \\
\end{array}$ & $\begin{array}{c}\mathrm{P} \\
(\%)\end{array}$ & $\begin{array}{c}\text { ANCE } \\
\mathrm{K} \\
(\%)\end{array}$ & $\begin{array}{c}\mathrm{S} \\
(\%) \\
\end{array}$ & $\begin{array}{c}\mathrm{Ca} \\
(\%) \\
\end{array}$ & $\begin{array}{l}\mathrm{Mg} \\
(\%) \\
\end{array}$ & $\mathrm{pH}$ \\
\hline Cowdung & 30.94 & 1.27 & 0.98 & 1.02 & 0.29 & 2.01 & 0.56 & 7.21 \\
\hline $\begin{array}{l}\text { Poultry } \\
\text { Manure }\end{array}$ & 31.52 & 2.87 & 1.28 & 1.23 & 0.48 & 2.83 & 0.74 & 8.10 \\
\hline Dolomite & - & - & - & - & - & 2.41 & 1.10 & 8.4 \\
\hline
\end{tabular}

\section{Planting Materials and Cultural Activities}

BARI OKRA-1 a wide popular, high yielding, early flowing, long-time bearing variety, developed by Bangladesh Agricultural Research Institute (BARI), Gazipur, Bangladesh was used as a test crop. The yield potential of the variety is 14-16 t/ha. A unit plot size of $4.0 \times 3.0 \mathrm{~m}$ was built after preparing the field thoroughly. Organic manures and chemical fertilizers were applied at different doses as per the treatment requirement. Dolomite, Poultry manure and Cowdung were applied at the time of final land preparation. The recommended dose of TSP, MoP, Gypsum and Zinc sulphate fertilizers were applied three days before sowing as a basal application, whereas urea was applied as three splits: 20, 40 and 60 days after sowing. Two seeds per hill were sown at a spacing of $60 \times 30 \mathrm{~cm}$ on 15 February 2021 . Thinning and other intercultural operations were done when required. The authors of the accepted manuscripts will be given a copyright form and the form should accompany your final submission.

\section{Harvesting and Data Collection}

Five randomly selected plants from each replication were used to collect various types of growth and yield contributing data for okra and their average value was considered as one replication for each parameter. Plant height, stem girth, number of branches per plant, number of leaves per plant, individual leaf area, plant fresh weight and plant dry weight were measured at 80 days after sowing. Fruits were collected every alternative day. Number of fruits per plant, fruit length, fruit girth and individual fruit weight were determined at each harvest. Yield per plot was converted to ton per hectare.

\section{E. Statistical Analysis}

Data regarding growth and yield traits were recorded and analyzed statistically with the help of computer package Statistics 10. Treatment means were separated by least 
significant difference (LSD) at 5\% level of probability as outlined by Gomez and Gomez (1984).

\section{RESUlTS AND DisCUSSION}

\section{A. Effect on Different Growth Attributes}

Growth attributes of okra responded significantly to the administered different integrated nutrient management approaches and liming material dolomite (Table II). Different amending materials had positive effects on the plant height okra and significantly varied from 87.93 to $114.10 \mathrm{~cm}$. The highest plant height $(114.10 \mathrm{~cm})$ was found in $\mathrm{T}_{3}(\mathrm{RDF}+\mathrm{PM}$ @ 3t ha $\left.{ }^{-1}\right)$, which was statistically similar with $\mathrm{T}_{2}(\mathrm{RDF}+$ Dolomite @ $\left.1 \mathrm{tha}^{-1}\right)$ and $\mathrm{T}_{3}\left(\mathrm{RDF}+\mathrm{CD} @ 5 \mathrm{tha}^{-1}\right)$. The lowest height $(87.93 \mathrm{~cm})$ was observed in $\mathrm{T}_{\mathrm{o}}$ (Control) treatment. The better performance of plant in PM treated plots in acidic soil might be the neutralization capacity of organic substances enhanced the supply of nutrients, and growth promoting constituents which may ultimately result in rapid cell growth as well as development of plants. These results coincide with the findings of Meena and Meena [17].

Stem girth of okra due to application of lime and organic matter along with chemical fertilizer was significantly varied from 4.51 to $7.73 \mathrm{~cm}$ (Table II). The treatment $\mathrm{T}_{4}(\mathrm{RDF}+\mathrm{CD}$ @ 5 $\left.\mathrm{t} \mathrm{ha}^{-1}\right)$ produced the highest stem girth $(7.73 \mathrm{~cm})$ which was in the same group with $\mathrm{T}_{3}\left(\mathrm{RDF}+\mathrm{PM} @ 3 \mathrm{tha}^{-1}\right)$ and the lowest $(4.51 \mathrm{~cm})$ was observed with $\mathrm{T}_{\mathrm{o}}(\mathrm{Control})$ treatment. Padamwar et al. [19] and Singh et al. [23] also found a progressive increase of stem girth in okra by the application of organic manures in acidic soil.

Integrated application of organic and inorganic fertilizer and lime significantly increased the number of branches per plant (Table II). The highest number of branches per plant (3.91) was recorded in treatment $\mathrm{T}_{3}\left(\mathrm{RDF}+\mathrm{PM} @ 3 \mathrm{t} \mathrm{ha}^{-1}\right)$ which was not significant differ with T2 (RDF + D @ $1 \mathrm{t} \mathrm{ha} \mathrm{h}^{-1}$ ) treatment (3.72) and the lowest (1.89) was recorded with T0 (Control) treatment. The treatment $\mathrm{T}_{3}(\mathrm{RDF}+\mathrm{PM} @$ $\left.3 \mathrm{tha}^{-1}\right)$ also gave the maximum number of leaves per plant (51.20) followed by $\mathrm{T}_{4}\left(\mathrm{RDF}+\mathrm{CD} @ 5 \mathrm{tha}^{-1}\right)$ treatment (50.33). The minimum number of leaves (36.67) was obtained with $\mathrm{T}_{\mathrm{o}}$ (Control) treatment. Thus, administered organic and inorganic amendments are likely to be responsible for the increased number of branches and leaves as it may help to lower soil acidity and boost nutrient availability to the plants [25]. These outcomes also summarized that organic matter had sustainable reclamation ability in acidic soil that ensure nutrient ability and better physiological activity of plants [14].

The data in Table II indicated that integrated nutrient management and liming had significant effect on individual leaf area $\left(\mathrm{cm}^{2}\right)$ of plants. Treatment $\mathrm{T}_{3}(\mathrm{RDF}+\mathrm{PM} @$ $\left.3 \mathrm{t} \mathrm{ha}^{-1}\right)$ asserted the highest surface area $\left(223.11 \mathrm{~cm}^{2}\right)$ for individual leaf where, the lowest $\left(152.35 \mathrm{~cm}^{2}\right)$ was observed with $\mathrm{T}_{\mathrm{o}}$ (Control) treatment. The research results clarify that from $\mathrm{OM}$ treated plots along with chemical fertilizer showed better nutrients uptake efficiently in acidic soil and ultimately gave better metabolic activity of plants. These results were in conformity with the findings of Wailare and Kesarwani [26].

SPAD value of okra plant leaves also significantly increased by the addition of different organic materials and lime along with chemical fertilizer (Table II). The highest SPAD value (45.08) was obtained with $\mathrm{T}_{4}(\mathrm{RDF}+\mathrm{CD} @$ $\left.5 \mathrm{t} \mathrm{ha}^{-1}\right)$ treatment followed by $\mathrm{T}_{3}\left(\mathrm{RDF}+\mathrm{PM} @ 3 \mathrm{t} \mathrm{ha}^{-1}\right)$ treatment (43.77) while the lowest SPAD value (35.69) was recorded with $\mathrm{T}_{0}$ (Control) treatment. This might be owing to higher availability of nitrogen resulting from mineralization of $\mathrm{OM}$ and their subsequent utilization by the plants. Our results are in consistent with the findings of Sahu et al. [21].

Integrated incorporation of organic and inorganic fertilizer significantly increased the fresh and dry weight of okra plant (Table 2). Plots treated with $\mathrm{T}_{3}\left(\mathrm{RDF}+\mathrm{PM} @ 3 \mathrm{t} \mathrm{ha} \mathrm{h}^{-1}\right.$ ) produced the significantly highest fresh and dry weight of plants (591.58 and $86.73 \mathrm{~g}$, respectively). These parameters were found lowest under $\mathrm{T}_{\mathrm{o}}$ (Control) treatment (410.50 and $60.44 \mathrm{~g}$ respectively). Thus, soil acidity had significantly reduced the dry mass of okra. However, the application of PM in acid soil enabled plants to accumulate more dry matter by improving soil fertility and nutrient uptake. A like information also observed by Suchitra and Manivannan, [24]. The integrated application of organic and inorganic fertilizer favoured the better photosynthates accumulation and consequently higher dry matter production of okra [1].

\section{B. Effect on Yield Attributes}

The data regarding yield attributes exhibited significant effect exerted by different integrated nutrient management (Fig. 1). Integrated addition of organic and inorganic fertilizer and lime management had positive impact on the number of fruits per plant. Application of $\mathrm{T}_{3}\left(\mathrm{RDF}+\mathrm{PM} @ 3 \mathrm{t} \mathrm{ha}^{-1}\right)$ treatment produced the highest (20.33) number of fruits per plant followed by $\mathrm{T}_{2}\left(\mathrm{RDF}+\mathrm{D} @ 1 \mathrm{t} \mathrm{ha}^{-1}\right)$ treatment (19.21) and the $\mathrm{T}_{0}$ (Control) produced lowest (11.29) number of fruits. These results revealed that application of organic manures combined with chemical fertilizers enriched both soils and plants with sufficient nutrients which ultimately improve crop yield. These results concur with the findings of Arjun et al. [3].

TABLE II: EFFECT OF INTEGRATED NUTRIENT MANAGEMENT ON DIFFERENT GROWTH ATTRIBUTES

\begin{tabular}{|c|c|c|c|c|c|c|c|c|}
\hline Treatments & $\begin{array}{l}\text { Plant height } \\
(\mathrm{cm})\end{array}$ & $\begin{array}{l}\text { Stem girth } \\
\quad(\mathrm{cm})\end{array}$ & $\begin{array}{c}\text { No. of } \\
\text { branches per } \\
\text { plant }\end{array}$ & $\begin{array}{c}\text { No. of } \\
\text { leaves per } \\
\text { plant } \\
\end{array}$ & $\begin{array}{c}\text { Individual } \\
\text { leaf area } \\
\left(\mathrm{cm}^{2}\right) \\
\end{array}$ & $\begin{array}{c}\text { Chlorophyll } \\
\text { (SPAD values) }\end{array}$ & $\begin{array}{c}\text { Plant fresh } \\
\text { wt. (g) }\end{array}$ & $\begin{array}{c}\text { Plant dry wt. } \\
\text { (g) }\end{array}$ \\
\hline $\mathbf{T}_{0}$ & $87.93 \mathrm{c}$ & $4.51 \mathrm{c}$ & $1.89 \mathrm{~d}$ & $36.67 \mathrm{c}$ & $152.35 \mathrm{~d}$ & $35.69 \mathrm{~d}$ & $410.50 \mathrm{~d}$ & $60.44 \mathrm{~d}$ \\
\hline $\mathbf{T}_{1}$ & $108.07 \mathrm{~b}$ & $6.96 \mathrm{~b}$ & $3.17 \mathrm{c}$ & $48.62 \mathrm{~b}$ & $176.48 \mathrm{c}$ & $42.43 c$ & $513.25 \mathrm{c}$ & $75.66 \mathrm{c}$ \\
\hline $\mathbf{T}_{2}$ & $111.53 \mathrm{ab}$ & $7.13 \mathrm{~b}$ & $3.72 \mathrm{ab}$ & $49.16 b$ & $195.00 \mathrm{~b}$ & $43.04 \mathrm{bc}$ & $572.33 \mathrm{~b}$ & $79.52 b$ \\
\hline $\mathbf{T}_{3}$ & $114.10 \mathrm{a}$ & $7.58 \mathrm{a}$ & $3.91 \mathrm{a}$ & $51.20 \mathrm{a}$ & $223.11 \mathrm{a}$ & $43.77 \mathrm{~b}$ & $591.58 \mathrm{a}$ & $86.73 \mathrm{a}$ \\
\hline $\mathbf{T}_{4}$ & $110.03 \mathrm{ab}$ & $7.73 \mathrm{a}$ & $3.65 \mathrm{~b}$ & $50.33 \mathrm{ab}$ & $198.14 \mathrm{~b}$ & $45.08 \mathrm{a}$ & $570.50 \mathrm{~b}$ & $78.30 \mathrm{~b}$ \\
\hline $\mathrm{CV}$ & 2.04 & 2.56 & 3.50 & 2.0 & 1.06 & 1.42 & 0.81 & 0.98 \\
\hline SE $( \pm)$ & 1.77 & 0.14 & 0.09 & 0.77 & 1.62 & 0.48 & 3.50 & 0.61 \\
\hline LSD & 4.08 & 0.33 & 0.215 & 1.77 & 3.74 & 1.12 & 8.08 & 1.409 \\
\hline
\end{tabular}

$\mathrm{T}_{0}=$ Control, $\mathrm{T}_{1}=$ Recommended dose of chemical fertilizers $(\mathrm{RDF}), \mathrm{T}_{2}=$ Dolomite $@ 1 \mathrm{t} \mathrm{ha}^{-1}+\mathrm{RDF}, \mathrm{T}_{3}=$ Poultry manure @ $3 \mathrm{t}$ ha ${ }^{-1}+\mathrm{RDF}, \mathrm{T}_{3}=\mathrm{Cow}$ dung @ $5 \mathrm{tha}^{-1}+\mathrm{RDF}$. 
Stem girth of okra due to application of lime and organic matter along with chemical fertilizer was significantly varied from 4.51 to $7.73 \mathrm{~cm}$ (Table II). The treatment $\mathrm{T}_{4}(\mathrm{RDF}+\mathrm{CD}$ @ 5 $\left.\mathrm{t} \mathrm{ha}^{-1}\right)$ produced the highest stem girth $(7.73 \mathrm{~cm})$ which was in the same group with $\mathrm{T}_{3}\left(\mathrm{RDF}+\mathrm{PM} @ 3 \mathrm{tha} \mathrm{h}^{-1}\right)$ and the lowest $(4.51 \mathrm{~cm})$ was observed with $\mathrm{T}_{\mathrm{o}}(\mathrm{Control})$ treatment. Padamwar et al. [19] and Singh et al. [23] also found a progressive increase of stem girth in okra by the application of organic manures in acidic soil.

Integrated application of organic and inorganic fertilizer and lime significantly increased the number of branches per plant (Table II). The highest number of branches per plant (3.91) was recorded in treatment $\mathrm{T}_{3}\left(\mathrm{RDF}+\mathrm{PM} @ 3 \mathrm{t} \mathrm{ha}^{-1}\right)$ which was not significant differ with T2 (RDF + D @

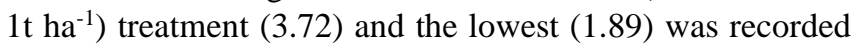
with T0 (Control) treatment. The treatment $\mathrm{T}_{3}(\mathrm{RDF}+\mathrm{PM} @$ $3 \mathrm{t} \mathrm{ha}^{-1}$ ) also gave the maximum number of leaves per plant (51.20) followed by $\mathrm{T}_{4}$ ( RDF + CD @ 5t ha ${ }^{-1}$ ) treatment (50.33). The minimum number of leaves (36.67) was obtained with $\mathrm{T}_{\mathrm{o}}$ (Control) treatment. Thus, administered organic and inorganic amendments are likely to be responsible for the increased number of branches and leaves as it may help to lower soil acidity and boost nutrient availability to the plants [25]. These outcomes also summarized that organic matter had sustainable reclamation ability in acidic soil that ensure nutrient ability and better physiological activity of plants [14].

The data in Table II indicated that integrated nutrient management and liming had significant effect on individual leaf area $\left(\mathrm{cm}^{2}\right)$ of plants. Treatment $\mathrm{T}_{3}(\mathrm{RDF}+\mathrm{PM} @$ $\left.3 \mathrm{t} \mathrm{ha}^{-1}\right)$ asserted the highest surface area $\left(223.11 \mathrm{~cm}^{2}\right)$ for

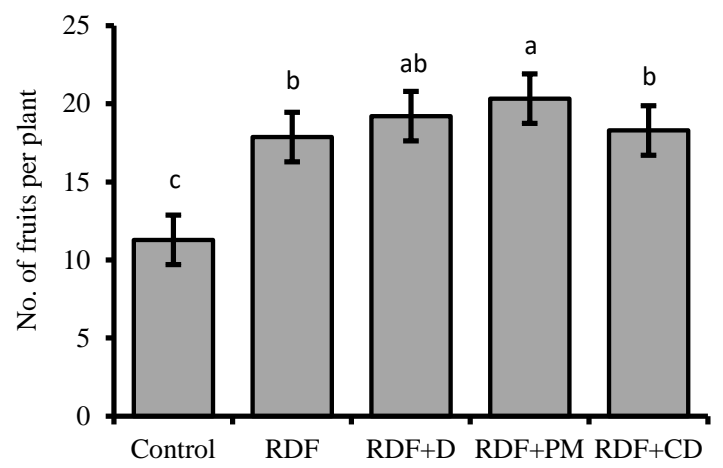

(a)

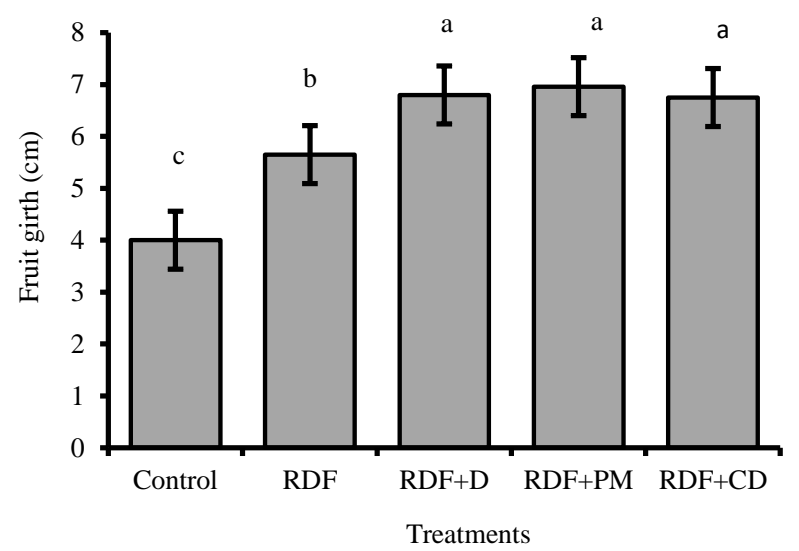

(c) individual leaf where, the lowest $\left(152.35 \mathrm{~cm}^{2}\right)$ was observed with $\mathrm{T}_{\mathrm{o}}$ (Control) treatment. The research results clarify that from OM treated plots along with chemical fertilizer showed better nutrients uptake efficiently in acidic soil and ultimately gave better metabolic activity of plants. These results were in conformity with the findings of Wailare and Kesarwani [26].

SPAD value of okra plant leaves also significantly increased by the addition of different organic materials and lime along with chemical fertilizer (Table II). The highest SPAD value (45.08) was obtained with $\mathrm{T}_{4}(\mathrm{RDF}+\mathrm{CD}$ @ $\left.5 \mathrm{t} \mathrm{ha}^{-1}\right)$ treatment followed by $\mathrm{T}_{3}\left(\mathrm{RDF}+\mathrm{PM} @ 3 \mathrm{t} \mathrm{ha}^{-1}\right)$ treatment (43.77) while the lowest SPAD value (35.69) was recorded with $\mathrm{T}_{0}$ (Control) treatment. This might be owing to higher availability of nitrogen resulting from mineralization of $\mathrm{OM}$ and their subsequent utilization by the plants. Our results are in consistent with the findings of Sahu et al. [21].

Integrated incorporation of organic and inorganic fertilizer significantly increased the fresh and dry weight of okra plant (Table II). Plots treated with $\mathrm{T}_{3}\left(\mathrm{RDF}+\mathrm{PM} @ 3 \mathrm{t} \mathrm{ha}^{-1}\right)$ produced the significantly highest fresh and dry weight of plants (591.58 and $86.73 \mathrm{~g}$, respectively). These parameters were found lowest under $\mathrm{T}_{\mathrm{o}}$ (Control) treatment (410.50 and $60.44 \mathrm{~g}$ respectively). Thus, soil acidity had significantly reduced the dry mass of okra. However, the application of PM in acid soil enabled plants to accumulate more dry matter by improving soil fertility and nutrient uptake. A like information also observed by Suchitra and Manivannan, [24]. The integrated application of organic and inorganic fertilizer favoured the better photosynthates accumulation and consequently higher dry matter production of okra [1].

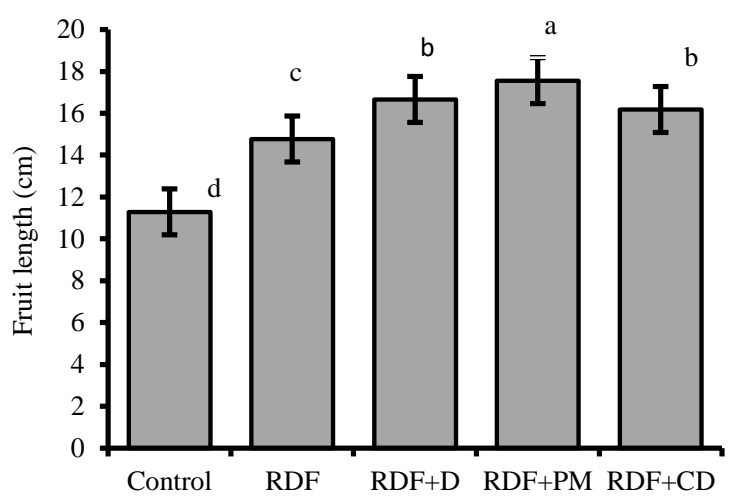

(b)

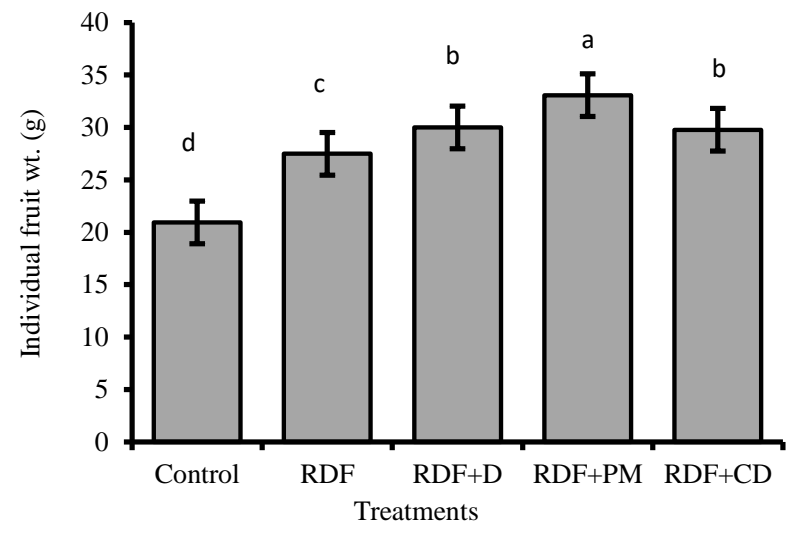

(d)

Fig. 1 Yield attributes of Okra (a) Number of fruits per plant, (b) Fruit length (cm), (c) Fruit girth (cm), and (d) Individual fruit weight (g) as influenced by integrated nutrient management. 
Data pertaining to fruit length $(\mathrm{cm})$ and girth $(\mathrm{cm})$ of okra were varied significantly by integrated addition of different organic and inorganic nutrients, shown in Fig. 1. The largest fruit length $(17.56 \mathrm{~cm})$ was obtained with $\mathrm{T}_{3}(\mathrm{RDF}+\mathrm{PM} @$ $\left.3 \mathrm{t} \mathrm{ha}{ }^{-1}\right)$ treatment and the shortest $(11.29 \mathrm{~cm})$ with $\mathrm{T}_{0}$ (Control) treatment. Fruit girth was the highest $(6.96 \mathrm{~cm})$ with $\mathrm{T}_{3}\left(\mathrm{RDF}+\mathrm{PM} @ 3 \mathrm{tha}^{-1}\right)$ treatment followed by $\mathrm{T}_{2}(\mathrm{RDF}+$ $\left.\mathrm{D} @ 1 \mathrm{t} \mathrm{ha} \mathrm{h}^{-1}\right)$ and $\mathrm{T}_{4}\left(\mathrm{RDF}+\mathrm{CD} @ 5 \mathrm{tha}^{-1}\right)$ treatment $(6.80$ and $6.75 \mathrm{~cm}$ respectively) and the lowest $(4.00 \mathrm{~cm})$ was with treatment $\mathrm{T}_{0}$ (Control).

The maximum fruit weight $\left(33.08 \mathrm{~g}\right.$ ) was produced in $\mathrm{T}_{3}$ $\left(\mathrm{RDF}+\mathrm{PM} @ 3 \mathrm{t} \mathrm{ha}^{-1}\right)$ treatment while the lowest (20.94 g) was produced in $\mathrm{T}_{\mathrm{o}}$ (Control) treatment (Fig. 1). The closest proximity data was noted in $\mathrm{T}_{2}\left(\mathrm{RDF}+\mathrm{D} @ 1 \mathrm{t} \mathrm{ha} \mathrm{h}^{-1}\right)$ and $\mathrm{T}_{4}$ $\left(\mathrm{RDF}+\mathrm{CD} @ 5 \mathrm{tha}^{-1}\right)$ treatment. Plot treated with PM were resulted the highest fruit length $(\mathrm{cm})$, fruit girth $(\mathrm{cm})$ which ultimately increased the individual fruit weight $(\mathrm{g})$ of okra. Organic amendment and liming might be influence both transformation and uptake of nutrient by plant in acidic soil, ultimately better biomass production and photosynthates accumulation [5], [11].

\section{Effect on Yield of Okra}

Integrated nutrient management through different organic and inorganic fertilizer and lime had significant impact on yield of Okra (Fig. 2). Plot treated with $\mathrm{T}_{3}$ (RDF + PM @ $\left.3 \mathrm{t} \mathrm{ha}^{-1}\right)$ treatment gave the maximum fruit yield per plant $(603.38 \mathrm{~g})$ and the lowest $(410.14 \mathrm{~g})$ was with $\mathrm{T}_{\mathrm{o}}$ (Control) treatment. Similarly, the significantly maximum fruit yield $\left(13.58 \mathrm{t} \mathrm{ha}^{-1}\right)$ was obtained in $\mathrm{T}_{3}\left(\mathrm{RDF}+\mathrm{PM} @ 3 \mathrm{tha}^{-1}\right)$ treated plot and the lowest $\left(8.56 \mathrm{t} \mathrm{ha}^{-1}\right)$ was with $\mathrm{T}_{\mathrm{o}}$ (Control) treatment. Overall, the treatment $\mathrm{T}_{3}\left(\mathrm{RDF}+\mathrm{PM} @ 3 \mathrm{t} \mathrm{ha}^{-1}\right)$ offered superior performance on yield of Okra. Integrated addition of different organic and inorganic amendments showed a substantial positive effect on the yield increase in acidic soil. It indicates that application of organic amendment and lime to soil may help to mitigate the negative impacts of soil acidity, enhance nutrient availability, and increase photosynthetes accumulation by plants. These results are in harmony with the findings of Madan and Sanjeev [13].

\section{CONCLUSION}

Integrated application of organic manures and/or lime with chemical fertilizers to acid soil significantly increased the growth and yield performance of okra. Overall, the study demonstrate that poultry manure plus chemical fertilizer management practice improved most of the growth attributes of okra including plant height, number of branches plant ${ }^{-1}$, number of leaves plant ${ }^{-1}$ and biomass production to a significant extent. However, cow dung treated plots also offered maximum stem girth, individual leaf area and chlorophyll content. The significantly enhanced yield and yield attributes were also obtained with poultry manure combined with chemical fertilizers. Based on the findings, it can be suggested that integrated application of organic amendments (poultry manure) or dolomite and inorganic fertilizers can be practiced for better growth and yield of okra in acidic soil. However, further trial is necessary in acidprone areas of Bangladesh for larger-scale recommendation.

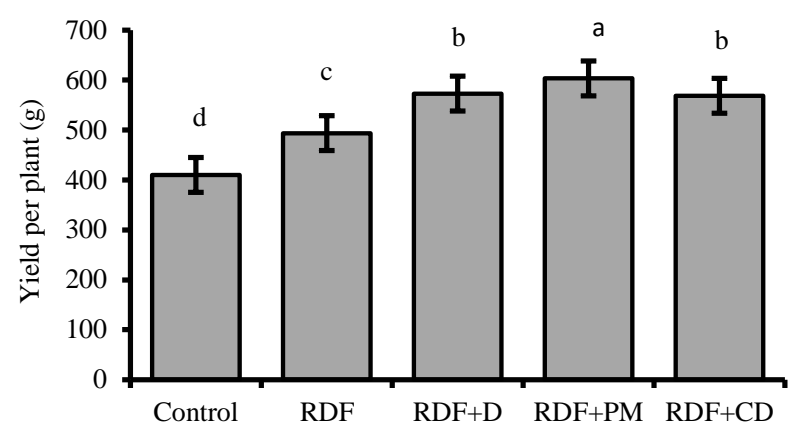

Treatments

(a)

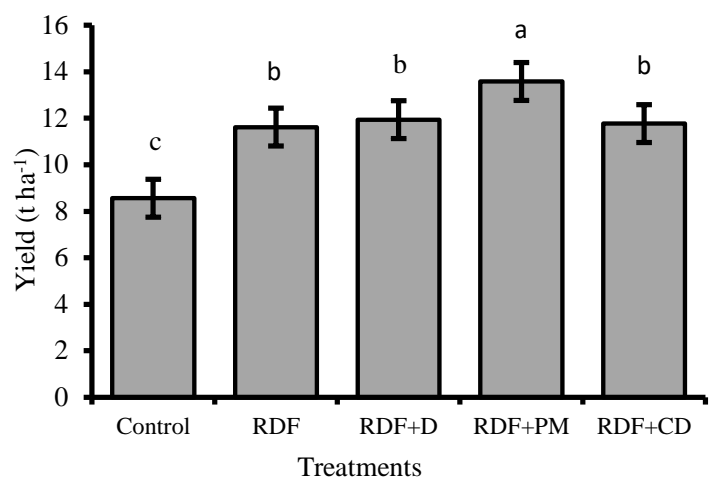

(b)

Fig. 2. Yield of Okra (a) Yield per plant (g), (b) Yield (t ha-1) as influenced by integrated nutrient management.

\section{ACKNOWLEDGMENT}

This work was funded by Department of Soil Science, Bangabandhu Sheikh Mujibur Rahman Agricultural University, Gazipur 1706, Bangladesh.

\section{REFERENCES}

[1] Akande MO, Oluwatoyinbo FI, Makinde EA, Adepoju AS, Adepoju IS. Response of okra to organic and inorganic fertilization. Nature and Science. 2010; 8(11): 261-266.

[2] Anonymous. Annual weather report. IPSA Meteorological Station, Salna, Gazipur-1706. 1989: 6-16.

[3] Arjun MA, Singh T, Shukla M, Namdeo K. Integrated Nutrient Management on growth, yield and quality of okra (Abelmoschus esculentus L. Moench). Annals of Plant and Soil Research. 2018; 20(4): 344-348.

[4] Bhindhu PS, Sureshkumar P, Abraham M, Kurien EK. Effect of liming on soil properties, nutrient content and yield of wetland rice in acid tropical soils of kerala. International Journal of Bio-resource and Stress Management. 2018; 9(4): 541-546.

[5] Cheng Y, Wang J, Mary B, Zhang JB, Cai ZC, Chang SX. Soil pH has contrasting effects on gross and net nitrogen mineralizations in adjacent forest and grassland soils in central alberta, canada. Soil Biology and Biochemistry, 2013, ch. 57, pp. 848-857.

[6] Fageria NK, Nascente AS. Management of soil acidity of south american soils for sustainable crop production. Advances in Agronomy. 2014; 128: 221-275.

[7] Gazey C, Davies S. Soil Acidity: A Guide for WA Farmers and Consultants; 2009.

[8] Hue NV. Correcting soil acidity of a highly weathered ultisols with chicken manure and sewage sludge. Communications in Soil Science and Plant Analysis. 1992; 23(3-4): 241-264.

[9] Iqbal M, Khan AG, Amjad, M. Soil physical health indices, soil organic carbon, nitrate contents and wheat growth as influenced by irrigation and nitrogen rates. International Journal of Agriculture and Biology. 2012; 14(1): 78-85. 
[10] Iqbal S, Khan HZ, Yaseen M. Impact of level and source of compost based organic material on the productivity of autumn maize (Zea mays L.). Pakistan Journal of Agricultural Sciences. 2014; 51(1): 41-47.

[11] Islam MR, Jahan R, Uddin S, Harine IJ, Hoque MA, Hassan S, et al. Lime and organic manure amendment enhances crop productivity of wheat-mungbean-t. aman cropping pattern in acidic piedmont soils. Agronomy. 2021; 11(8): 1595.

[12] Jamwal JS. Productivity and economics of maize (Zea mays)-wheat (Triticum aestivum) cropping system under integrated nutrient supply system in rainfed areas of jammu. Indian Journal of Agronomy. 2005; 50(2): 110-112

[13] Madan L, Sanjeev K. Effect of chemical and organic fertilizers on growth, flowering and yield of okra (Abelmoschus esculentus L. Moench) cv. Arka Anamica. Agriways. 2016; 4(1): 69-72.

[14] Mahapatra A, Barik AK., Mishra GC. Effect of integrated nutrient management (INM) on growth and yield of baby corn (Zea mays L.). Environment and Ecology. 2018; 36(1A): 338-342.

[15] Maheswarappa HP, Nanjappa HV, Hegde MR. Effect of Planting Material, plant population and organic manures on growth components and yield of galangal (Kaempferia galanga) when grown as intercrop in coconut garden. Indian Journal of Agricultural Science. 2001; 71(3): 183-186.

[16] Martha M, Shapiro CA. Management strategies to reduce the rate of soil acidification. University of Nebraska-Lincoln Extension, Institute of Agriculture and Natural Resources; 2015.

[17] Meena DC, Meena ML. Effect of integrated nutrient management on growth parameters of okra (Abelmoschus esculents L. Moench). Chemical Science Review and Letters. 2018; 7(26): 582-585.

[18] Miaha R, Methelaa NJ, Ruhib RA. Effect of integrated nutrient management on growth and yield of okra. Tropical Agrobiodiversity. 2020; 1(2): 72-76.

[19] Padamwar SB, Dakore HG. Role of organic fertilizers in enhancing the growth attributes, yield and nutritional quality of knolkhol (kohlarabi). International Journal of Plant Sciences. 2011; 6(1): 19-21.

[20] Rahman MA, Chikushi J, Duxbury JM, Meisner CA, Lauen JG, Yasunaga E. Chemical control of soil environment by lime and nutrients to improve the productivity of acidic alluvial soils under ricewheat cropping system in Bangladesh. Environmental Control in Biology. 2005; 43(4): 259-266.

[21] Sahu YK, Chaubey AK, Mishra VN, Rajput AS, Bajpai RK. Effect of integrated nutrient management on growth and yield of rice (Oryza sativa L.) in Inceptisols. Plant Archives. 2015; 15(2): 983-986.

[22] Singh VP, Maiti RK, Kalpana K, Hernandez-Pinero J. Research advances in okra or bhendi (Abelmoschus esculentus L.)-A review. Research on Crops. 2007; 8(2): 261.

[23] Singh SK, Sanjay K, Yadav YC, Adesh K. Effect of NPK levels on growth, yield and quality of okra (Abelmoschus esculentus). HortFlora Research Spectrum. 2012; 1(2): 190-192.

[24] Suchitra S, Manivannan K. Studies on the influence of organic inputs on the growth and yield of bhendi, vegetable cowpea in various seasons. Indian Journal of Plant Sciences. 2012; 1(2-3): 124-132.

[25] Thirunavukkarasu M, Balaji $T$. Effect of integrated nutrient management on growth attributes, biomass yield, secondary nutrient uptake and quality parameters of bhendi (Abelmoschus esculentus L.). Journal of Applied and Natural Science. 2015; 7(1): 165-169.

[26] Wailare AT, Kesarwani A. Effect of integrated nutrient management on growth and yield parameters of maize (Zea mays L.) as well as soil physico-chemical properties. Journal of Scientific and Technical Research. 2017; 1(2): 294-298.

[27] Wong MTF, Swift RS. Application of fresh and humified organic matter to ameliorate soil acidity. In Proceedings of the 9th International Conference of the International Humic Substance Society. Understanding and Managing Organic Matter in Soils, Sediments and Water. 2001; pp. 235-242. 